\title{
Environmental Stressors and Epigenetic Control of the Hypothalamic-Pituitary- Adrenal Axis
}

\author{
Richard S. Lee Akira Sawa \\ Department of Psychiatry and Behavioral Sciences, Johns Hopkins University School of Medicine, Baltimore, Md., USA
}

\section{Key Words}

Hypothalamic-pituitary-adrenal axis · Stress .

Glucocorticoids · Cortisol · Epigenetics · DNA methylation .

Histones $\cdot$ Mood disorders $\cdot$ Anxiety disorders

\begin{abstract}
In this review, we provide a brief summary of several key studies that broaden our understanding of stress and its epigenetic control of the function and behavior of the hypothalamic-pituitary-adrenal (HPA) axis. Clinical and animal studies suggest a link among exposure to stress, dysregulation of the HPA axis, and susceptibility to neuropsychiatric illnesses. Recent studies have supported the notion that exposure to glucocorticoids and stress in various forms, durations, and intensities during different periods of development leads to long-lasting maladaptive HPA axis response in the brain. They demonstrate that this maladaptive response is comprised of persistent epigenetic changes in the function of HPA axis-associated genes that govern homeostatic levels of glucocorticoids. Stressors and/or disruption of glucocorticoid dynamics also target genes such as brain-derived neurotrophic factor (BDNF) and tyrosine hydroxylase (TH) that are important for neuronal function and behavior. While a definitive role for epigenetic mechanisms remains unclear,
\end{abstract}

these emerging studies implicate glucocorticoid signaling and its ability to alter the epigenetic landscape as one of the key mechanisms that alter the function of the HPA axis and its associated cascades. We also suggest some of the requisite studies and techniques that are important, such as additional candidate gene approaches, genome-wide epigenomic screens, and innovative functional and behavioral studies, in order to further explore and define the relationship between epigenetics and HPA axis biology. Additional studies examining stress-induced epigenetic changes of HPA axis genes, aided by innovative techniques and methodologies, are needed to advance our understanding of this relationship and lead to better preventive, diagnostic, and corrective measures.

(c) 2014 S. Karger AG, Basel

\section{Introduction}

Due to high prevalence rates, strong patterns of chronicity, and mental debilitation, psychiatric disorders such as depression are projected to be the second leading cause of disability worldwide by 2020 [1]. Efforts at identifying genetic determinants of major psychiatric disorders began in the 1980s with linkage studies and later with ge-

\section{KARGER}

E-Mail karger@karger.com

www.karger.com/nen
(C) 2014 S. Karger AG, Basel

0028-3835/14/1004-0278\$39.50/0
Richard S. Lee

Department of Psychiatry and Behavioral Sciences

Johns Hopkins University School of Medicine

720 Rutland Ave., Ross 1068, Baltimore, MD 21205 (USA)

E-Mail richardlee@jhmi.edu 
Fig. 1. Disruption of the HPA axis and behavior by stress or glucocorticoids.

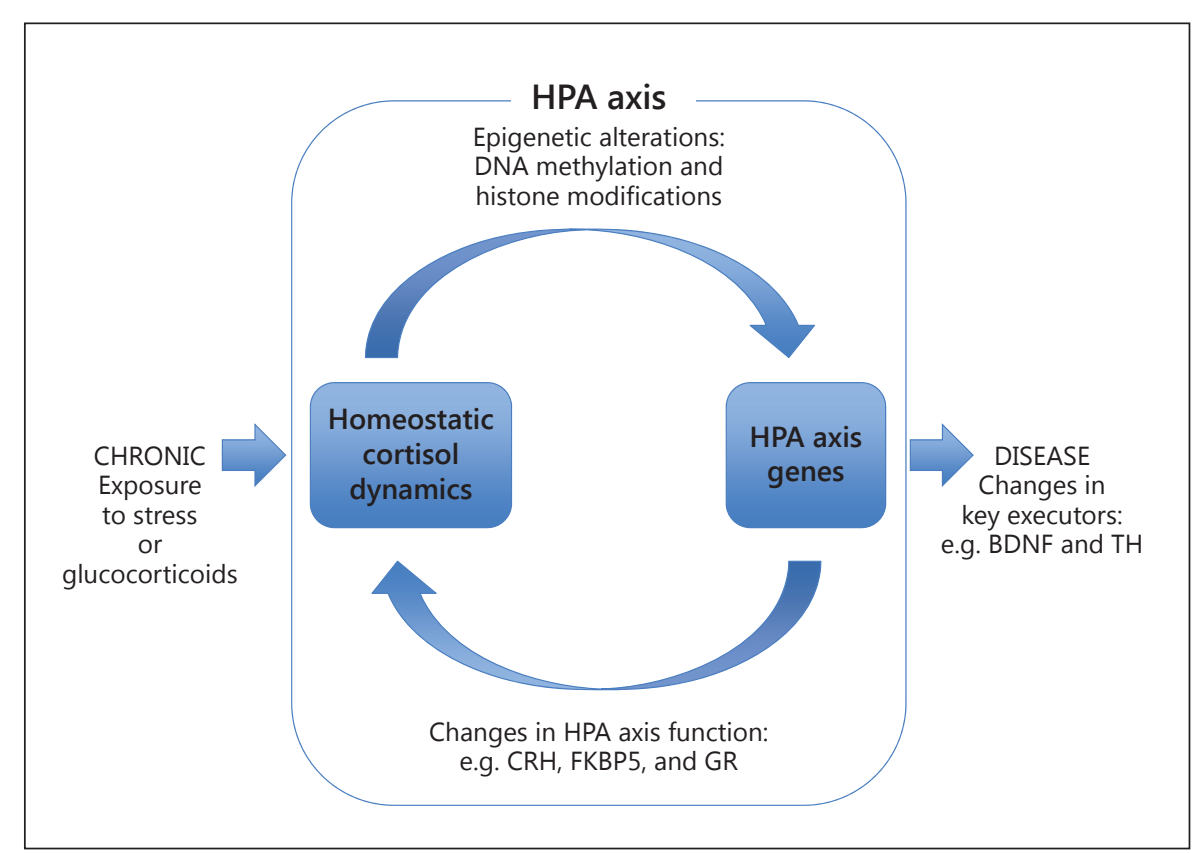

nome-wide association studies (GWAS) [2]. Over the past several years, efforts at identifying epigenetic mechanisms of gene function have also gained traction. Despite high heritability of a majority of psychiatric disorders, some conditions, such as major depressive disorder and posttraumatic stress disorder (PTSD), have a relatively lower degree of heritability and further suggest potential involvement of environmental factors [3-5]. In addition, there have been studies that have linked environmental influences, such as diet and nutrition [6,7], maternal immune response $[8,9]$, and stress [10-12], as risk factors to what are otherwise highly heritable disorders.

\section{Stress as a Nongenetic Risk Factor}

One of the more prevalent and well-studied environmental influences is stress. Preclinical [13-15], epidemiological [16], and clinical studies [17-19] suggest a strong link among exposure to stress, dysregulation of the hypothalamic-pituitary-adrenal (HPA) axis, and susceptibility to neuropsychiatric illnesses. Studies in humans and animal models have reported that stressors in their various forms, durations, and intensities all place significant burden on the HPA axis and its ability to properly regulate the glucocorticoid dynamics [20,21]. Specifically, activation of the HPA axis by perception and experience of the stressor typically leads to the production and release of the glucocorticoid cortisol, which is the neuroendocrine mediator of the 'fight or flight' response. However, in cases of exposure to trauma or chronic stress, the homeostatic, negative-feedback regulation of the HPA axis becomes disrupted, leading to aberrant glucocorticoid levels that can persist even in the absence of additional stressors. For instance, clinical studies of subjects suffering from PTSD or those who have experienced childhood traumas have reported abnormal baseline cortisol levels in measurements such as the cortisol awakening response [22, 23] or dysregulation of cortisol response during tests designed to challenge HPA axis function, such as the dexamethasone suppression test (and corticotropin-releasing hormone/ dexamethasone) [24-26] or the Trier Social Stress Test [27]. Findings from such studies imply that stressors or traumas that provoke HPA axis function above and beyond the acute 'fight or flight' response lead to changes in not only tissue-specific processes that are influenced by glucocorticoid signaling, but also those that directly regulate and mediate the stress response itself (fig. 1).

This link between stress- or glucocorticoid-induced HPA axis dysregulation and further disruption of glucocorticoid dynamics is believed to have detrimental consequences on mood and behavior. One disease that exemplifies this relationship is Cushing's disease, where adrenocorticotropic hormone (ACTH)-secreting pituitary adenomas are immune to glucocorticoid-induced suppression of ACTH and endogenous cortisol release during the 
Table 1. Representative stress-/HPA axis-associated genes

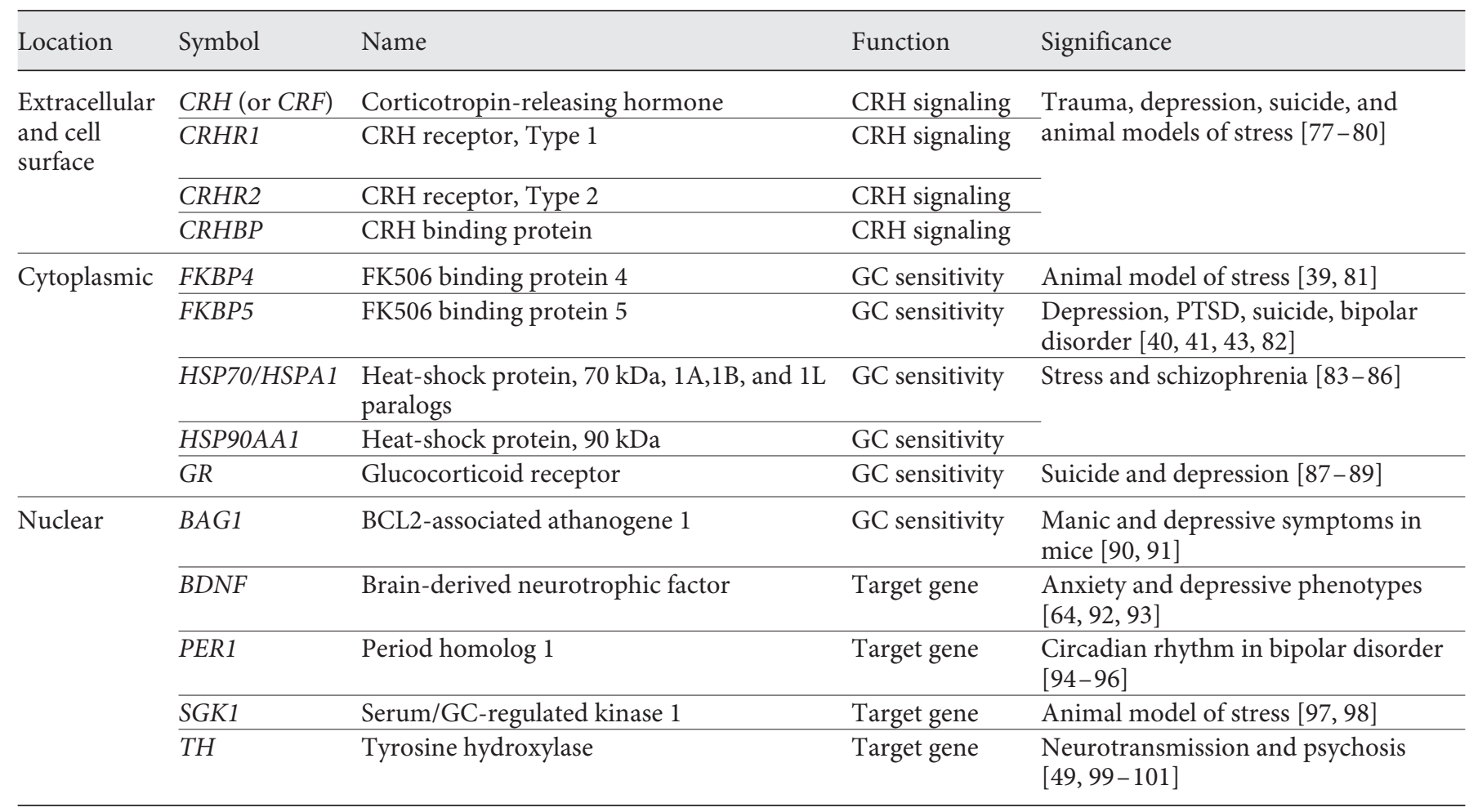

GC = Glucocorticoid

dexamethasone suppression test. Remarkably, depression is comorbid in 60-90\% of these Cushing's patients [28-30], and resolution of both hypercortisolemia and depressive symptoms by surgical removal of the adenomas suggests a causal role for hypercortisolemia and HPA axis dysregulation in the mood of these patients $[29,31]$. Similarly, a landmark epidemiological study that examined hundreds of thousands of patients who were prescribed glucocorticoids (i.e., iatrogenic Cushing's syndrome) for nonpsychiatric disorders found a significant increase in cases of depression, suicide, mania, and anxiety associated with glucocorticoid therapy [32]. Taken together, these studies highlight the importance of stress and its principal in vivo agent cortisol in mood regulation and necessitate a closer examination of the processes that govern this relationship.

\section{Epigenetics and the HPA Axis: Case Studies}

The following studies using animal models and epigenetic tools have reported associations between behavioral changes relevant to mental illness and genes that are either targets of or directly regulate HPA axis function (HPA axis genes; table 1).

\section{Influences of Poor Maternal Care on \\ Neurodevelopment}

Stress-mediated epigenetic modifications may be more pronounced during the stress-vulnerable, early-life period where regions implicated in emotionality and stress reactivity such as the hippocampus, amygdala, and the prefrontal cortex are undergoing rapid changes in dendritic density, myelination, and synaptic plasticity $[33,34]$. Weaver et al. [35] have reported that good maternal nursing behavior (vs. neglect) is required for proper postnatal epigenetic programming of HPA axis function in adulthood. They examined exon $\mathrm{I}_{7}$ promoter region of $\mathrm{Nr} 3 \mathrm{cl}$ (glucocorticoid receptor, $\mathrm{Gr}$ ) and found that $\mathrm{CpG}$ dinucleotides that reside within the binding sites for the nerve growth factor-inducible protein NGFIA are heavily methylated in the pups that experienced poor nursing behavior. This differential methylation state was associated with decreased binding to NGFI-A, decreased $\mathrm{Nr} 3 \mathrm{cl}$ expression, elevated plasma corticosterone 
levels, and anxiety-mediated behaviors [36]. A similar postnatal study using 'stress-abusive' nursing mothers documented lasting DNA methylation changes in $B d n f$, a target gene of glucocorticoid signaling [37] that encodes an important neurotrophic factor, which was associated with maternal maltreatment when the abused female pups themselves became nursing mothers [38].

\section{Conditions Associated with Anxiety Disorders}

Other bodies of work modeling anxiety disorders established additional components of the glucocorticoid receptor (GR)-associated signaling complex as targets of glucocorticoid exposure and traumatic stress. One such gene is FK506 binding protein-5 (Fkbp5), a chaperone protein and primary regulator of intracellular GR-signaling [39], which has been implicated in numerous association studies of depression, bipolar disorder, and PTSD [40-43]. Work by Lee et al. [44] demonstrated that glucocorticoid administration to adolescent animals is capable of inducing loss of DNA methylation and increase in expression of $F k b p 5$. Results showed that methylation alterations observed in the glucocorticoid response element (GRE) persisted into adulthood and were associated with anxiety-like behavior [45]. Another study examined human lymphocytes derived from subjects exposed to childhood trauma and reported loss of DNA methylation in a blood-specific, intronic region of the FKBP5 gene [46]. Their findings that linked DNA methylation of FKBP5 and its transcription were consistent with previous studies of this gene in the context of glucocorticoid resistance and hypercortisolemia. Interestingly, a crucial SNP (rs1360780) implicated in several studies of depression and PTSD, and located adjacent to the site of the epigenetic changes, had a moderating effect on DNA methylation and expression, demonstrating a gene-environment interaction [46].

\section{Conditions Associated with Adult-Onset Depression}

In adults, social defeat stress has been shown to underlie profound changes in social interactive behavior and reduction of $B d n f$, both of which become reversed following treatment with the tricyclic antidepressant imipramine [47]. The same psychosocial paradigm produced loss of methylation and increase in expression of the corticotropin-releasing factor $(\mathrm{Crf})$ gene in stress-vulnerable mice, with imipramine reversing methylation loss at a potentially important cyclic AMP (cAMP) response element (CRE) [48]. Stress-induced increase in hypothalamic $\mathrm{Crf}$ is consistent with elevation of plasma corticosterone. Similarly, social isolation stress imposed on adolescent mutant Disrupted-in-Schizophrenia (DISC1) transgenic mice resulted in elevation of plasma corticosterone and hypermethylation of the promoter of the tyrosine hydroxylase (Th) gene. In this model of gene-environment interaction, Th promoter of neurons that projected to the mesocortical, but not mesolimbic, brain became selectively hypermethylated [49]. In addition, epigenetic and behavioral deficits associated with isolation stress were prevented when the animals were concurrently treated with the GR antagonist mifepristone (RU486). This implicated glucocorticoid signaling in epigenetic control of behavior.

While it is unclear at this time as to how different genes, anatomical regions, and developmental periods contribute to the observed behavioral changes, these studies nonetheless have begun to elucidate crucial mechanisms that govern depression-related behaviors. As the field of stress epigenetics is emerging, many of such studies are needed to address the gap in knowledge and integrate these important findings under a unifying framework.

\section{Epigenetics and the HPA Axis: Mechanisms}

The above studies demonstrate that chronic exposure to stressors or glucocorticoids affects, via uncharacterized signaling, intracellular enzymes such as DNA methyltransferases and/or histone acetyl transferases to transduce environmental stressors into methylation of nucleotide cytosines or acetylation and/or methylation of amino acid lysine. Such modifications in turn can have a lasting influence on gene function by affecting DNA binding of transcription factors or by altering chromatin structure. Emerging evidence points to epigenetic and functional disruption by the direct action of glucocorticoids of two types of stress-associated genes: (1) those that directly govern HPA axis function by modulating intracellular glucocorticoid signaling and sensitivity, and (2) those that cause long-term dysregulation of neuronal processes, such as neurotransmission, that are important for proper mood, emotions, and cognition. For the latter, it is not clear whether the effect is a direct result of the stressor or altered cortisol levels following dysregulation of genes that modulate its signaling. For both types of genes, it is also unclear as to what extent other hormones and neurotransmitters associated with the stress response, in addition to glucocorticoids, may play a role in shaping HPA-axis function. 
Epigenetic Alteration of HPA Axis Genes: Direct

Influences on Glucocorticoid Signaling and Sensitivity

Few studies demonstrate that stress exposure or glucocorticoid administration epigenetically alters the function of genes that directly modulate glucocorticoid signaling. One of the primary modulators of glucocorticoid signaling is GR itself. Work on maternal nursing behavior has reported high DNA methylation and low histone acetylation of $G r$ exon $\mathrm{I}_{7}$ associated with poor maternal behavior, at the binding site for the transcription factor NGFI-A [35]. With diminished binding for this protein, GR levels were lower, and plasma glucocorticoid levels were more pronounced following an acute-stressor challenge, suggesting that the quality of maternal behavior, or postnatal stress, can shape HPA axis development. Consistently, there are multiple negative GREs (nGREs) within the intronic regions of $G r$, and studies have reported a reduction of GR with stress [50] or glucocorticoid treatment $[51,52]$.

A similar target gene that directly alters glucocorticoid signaling is FKBP5, which binds to GR and co-regulates intracellular glucocorticoid signaling. The role of FKBP5 in glucocorticoid resistance and hypercortisolemia is demonstrated in the New World monkeys, where overexpression of FKBP5 causes reduced affinity of GR for cortisol $[53,54]$. Our group reported that glucocorticoid-induced loss of methylation and increase in expression of Fkbp5 is tissue-specific and dose-dependent $[44,45]$. The underlying mechanism of 'action at a distance' by these distant intronic GREs has recently been characterized: the examined risk allele adjacent to one of the intronic GREs formed a chromatin loop with the promoter region and allowed the GR/GRE to act as a long-distance enhancer to promote transactivation of FKBP5 [46]. The overall effect was a more robust transcriptional activity and higher levels of FKBP5 that in turn limited intracellular GR signaling and promoted glucocorticoid resistance.

Another target of GR signaling that alters HPA-axis function is the gene that encodes the corticotropin-releasing factor (CRF or corticotropin-releasing hormone, $\mathrm{CRH})$. Mice that were susceptible to social defeat stress, as determined by avoidance of social interaction, displayed an increase in activation and decrease in DNA methylation of the Crf promoter [48]. The site of methylation change coincided with a CRE, and the authors demonstrate increased response to cAMP when the promoter is hypomethylated. Interestingly, stress-induced behavior and epigenetic alterations became abrogated when imipramine was administered. Knockdown of ex- pression of Crf by introduction of siRNA into the paraventricular nucleus of the hypothalamus (PVN) exhibited the same mitigation of social avoidance behavior, suggesting that CRF-induced plasma glucocorticoid levels can influence depressive behaviors [48]. Similar to $G r$, regulation of $C r f$ is a well-established negative-feedback paradigm, where an nGRE adjacent to the CRE is responsible for promoting stress- or glucocorticoid-induced suppression of transcription and subsequent reduction of ACTH release from the pituitary $[55,56]$. More recent studies have also reported elevation of $C r f$ mRNA in animals with targeted GR deletions to the PVN [57] and formation of a repressive chromatin complex at the Crf promoter following glucocorticoid treatment [58], with another study suggesting that repression via GR signaling may be dependent on treatment duration and independent of the nGRE [59].

\section{Epigenetic Alteration of Genes That Influence \\ Neuronal Processes}

In addition to HPA axis genes that directly alter plasma glucocorticoid levels, some are directly involved in the regulation of neuron function and neurotransmission. For example, work by Tsankova et al. [47] focused on epigenetic control of hippocampal $B d n f$, a neurotrophin gene necessary for cell survival and neuroprotection [60, 61]. Regulation of splice variants of $B d n f$ III and IV implicated histone-mediated mechanisms, where social defeat stress has caused methylation of histone $\mathrm{H} 3$ at lysine residue 27, and subsequent reduction in transcription was then rescued by inhibition of histone deacetylases with imipramine [47]. Another report showed a robust increase in methylation as a potential mechanism for reduction of $B d n f$ mRNA in the maltreated pups [38]. Similar to the Crf promoter, the methylated site within exon IV of $B d n f$ includes a CRE, providing the means by which methylation of DNA can interfere with binding of the CREB transcription factor [38]. In both instances, it is unclear as to how these epigenetic changes occur, although it is presumed to be by glucocorticoid signaling, as both genes are direct targets [62-64]. In addition, Niwa et al. [49] showed that epigenetic downregulation of the Th gene in the mesocortical dopaminergic neurons is mediated by GR, as demonstrated by the reversal of stress-induced phenotypes, including behavior, with the glucocorticoid antagonist RU486. 
Table2.Summary of requisite knowledge and technical refinements

\begin{tabular}{ll}
\hline Molecular & - Identification and characterization of proteins \\
mechanisms & and enzymes that co-regulate HPA axis genes \\
& with GR \\
& - Comprehensive list of glucocorticoid targets by \\
& GR-seq, ChIP-seq, or methylation arrays of brain \\
& tissues \\
\hline Animal & - Knock-out and transgenic animals to study the \\
models & role of HPA axis genes on behavior \\
& - Refinement of techniques for target cell-type \\
& enrichment \\
& - Identification of epigenetic marks in peripheral \\
& tissues that serve as a proxy for those in the brain \\
& - Tools to site-specifically alter the epigenome \\
\hline Human & Comprehensive list of glucocorticoid targets by \\
studies & GR-seq, ChIP-seq, or methylation arrays of brain \\
& tissues \\
& - Refinement of techniques for target cell-type \\
& enrichment of postmortem brain tissues \\
& Validation of peripheral biomarkers \\
& - Dene-environment interactions \\
& epigenetic enzymes or epigenomic loci
\end{tabular}

\section{Future Direction of Epigenetics of Stress and HPA Axis Biology: From Basic Science to Clinical Applications}

Despite the innovative methods employed by the case studies, additional tools and more comprehensive experiments are necessary to clearly establish the role of epigenetics in stress-induced alterations and subsequent vulnerability to psychiatric illnesses (table 2).

\section{Molecular Studies of Basic Mechanisms}

Basic science experiments elucidating the underlying mechanism of stress- or glucocorticoid-induced epigenetics are necessary. One of the first tasks of such experiments is to identify specific methyltransferase and demethylase activities for DNA and histones. Given the ability of GR to act as both an activator and repressor of transcription, through occupation of GREs or nGREs, respectively, along with its capacity as a transrepressor through DNA-independent, tethering mechanisms [65, 66], conditions under which epigenetic changes occur and where inter-study differences arise, such as specific tissues or types of stressors, need to be identified and rigorously replicated. In addition, it is important to

Epigenetic Consequences of Stress on the HPA Axis and Behavior identify the complexes of proteins and transcription factors that coordinate the physiological processes in response to environmental factors, as their characterization will broaden our understanding of the epigenetic mechanisms and lead to more target-specific and efficacious drug interventions. Lastly, there is a great need to comprehensively identify stress and glucocorticoid targets in brain tissues. A comparison of a few studies that have used GR-mediated chromatin immunoprecipitation (ChIP) in combination with hybridization on microarray chips (ChIP-chip) or sequencing on highthroughput platforms (ChIP-seq) shows that there is a general lack of common genomic targets of glucocorticoids in different cell types and brain regions [67]. Therefore, unbiased GR- or histone-mediated ChIP experiments and innovative DNA methylation screens [68] performed in different brain regions or populations of neurons of similar function are necessary to identify sets of genes or pathways that are specific for each tissue type. For instance, a recent study that identified genomic targets of GR by ChIP-seq of the hippocampus of rats treated with glucocorticoids [69] is likely to differ in its list of targets from a similar study employing a stress model and investigating the PVN. These proposed studies will shed light on common epigenetic mechanisms that govern the regulation of HPA axis genes and behavior.

\section{Preclinical Animal Models}

Animal models will also prove indispensable in understanding HPA axis stimulation and long-term behavioral consequences. First, knock-out and transgenic animals of HPA axis genes that are selected through genomic screens or allelic variations implicated in human studies, such as Crf, Gr, Fkbp5, Bdnf, and Disc1 [48, 49, 70-72], can be generated to demonstrate their causal roles in stress-related behavior. Consequently, similar to human genetic studies, epigenetic studies that incorporate interactions among different epigenomic loci and with genetic variations (gene-environment interactions) are needed to assess stress susceptibility and resilience. Second, refinement of methodologies specific for epigenetics, such as those needed for addressing cellular heterogeneity, can be implemented, for instance, by targeting of specific neuroanatomical subregions such as the PVN [48], dissection of specific neuronal subpopulations by laser-capture microdissection [73], and fluorescence-activated cell sorting of projection-specific dopaminergic neurons [49]. Third, identification of epigenetic correlates of stress exposure between brain regions 
and peripheral tissues will be enormously useful for translational research. Lastly, tools to site-specifically manipulate the epigenome, made possible by recent advances in zinc finger targeting of specific enzymatic activities [74-76], can be implemented to mitigate the negative impact of environmental factors.

\section{Human Studies}

Foundational knowledge established by basic science research and animal models can be used to strengthen human studies conducted in clinical settings or on postmortem brain tissues. For instance, epigenomic loci in blood that might serve as proxy for those in brain tissues of animals need to be validated with human specimens to assess their potential in determining cumulative stress exposure or susceptibility to mood disorders. Further, causal relationships between alterations of HPA axis genes and behavioral deficits derived from animal models can provide a stronger argument for pivotal roles of specific genes in diseases. We optimistically state that similar benefits may be obtained in augmenting imaging studies by honing in on specific regions and circuitry implicated in animal studies. Epigenomic studies in humans can also build on top of GWAS to identify gene-environment interactions. Finally, one of the key tenets of epigenetics is the concept of change. As such, development of 'epigenetic' medications that target specific enzymatic processes or even specific epigenomic targets to reverse disease phenotype needs to be pursued.

\section{Conclusion}

In this article, we have reviewed several studies that provide a potential mechanistic link among stress/glucocorticoid exposure, HPA axis function, and behavior. These studies suggest: (1) chronic exposure to stressors or glucocorticoids causes a persistent disruption of the glucocorticoid dynamics; (2) altered cortisol levels cause deterioration of the HPA axis negative feedback and chronic dysregulation of genes that control glucocorticoid signaling and sensitivity, and (3) persistent disturbances in glucocorticoid signaling can have a negative impact on behavior by epigenetic control of genes that regulate mood and neurotransmission. Finally, these case studies provide a strong motivation to pursue and implement crucial experiments and techniques, such as genomewide screens and neuron enrichment procedures, respectively, in order to establish a unified framework for a more comprehensive understanding of stress biology.

\section{Acknowledgements}

We thank Ms. Yukiko Lema for her assistance with the preparation of the manuscript. This work was supported by USPHS grants of MH-084018 (A.S.), MH-094268 Silvio O. Conte center (A.S.), MH-069853 (A.S.), MH-085226 (A.S.), MH-088753 (A.S.), MH-092443 (A.S.), MH-091230 (A.S.), Stanley (A.S.), RUSK (A.S.), S-R foundations (A.S.), NARSAD (A.S., R.S.L.), Maryland Stem Cell Research Fund (A.S.), Margaret Ann Price Investigator Fund (R.S.L.) and the James Wah Mood Disorders Scholar Fund via the Charles T. Bauer Foundation (R.S.L.).

\section{References}

1 Lopez AD, Murray CC: The global burden of disease, 1990-2020. Nat Med 1998;4:12411243.

2 Burmeister M, McInnis MG, Zollner S: Psychiatric genetics: progress amid controversy. Nat Rev Genet 2008;9:527-540.

3 Sullivan PF, Daly MJ, O’Donovan M: Genetic architectures of psychiatric disorders: the emerging picture and its implications. Nat Rev Genet 2012;13:537-551.

4 True WR, Rice J, Eisen SA, Heath AC, Goldberg J, Lyons MJ, Nowak J: A twin study of genetic and environmental contributions to liability for posttraumatic stress symptoms. Arch Gen Psychiatry 1993;50:257-264.

-5 Sartor CE, Grant JD, Lynskey MT, McCutcheon VV, Waldron M, Statham DJ, Bucholz KK, Madden PA, Heath AC, Martin NG, Nelson EC: Common heritable contributions to low-risk trauma, high-risk trauma, posttraumatic stress disorder, and major depression. Arch Gen Psychiatry 2012;69:293-299.
-6 Jacka FN, Pasco JA, Mykletun A, Williams LJ, Hodge AM, O'Reilly SL, Nicholson GC, Kotowicz MA, Berk M: Association of Western and traditional diets with depression and anxiety in women. Am J Psychiatry 2010;167: 305-311.

7 Susser ES, Lin SP: Schizophrenia after prenatal exposure to the Dutch Hunger Winter of 1944-1945. Arch Gen Psychiatry 1992;49: 983-988.

-8 Atladottir HO, Henriksen TB, Schendel DE, Parner ET: Autism after infection, febrile episodes, and antibiotic use during pregnancy: an exploratory study. Pediatrics 2012; 130:e1447-e1454.

-9 Yolken RH, Dickerson FB, Fuller Torrey E: Toxoplasma and schizophrenia. Parasite Immunol 2009;31:706-715.

10 McEwen BS, Gianaros PJ: Central role of the brain in stress and adaptation: links to socioeconomic status, health, and disease. Ann NY Acad Sci 2010;1186:190-222.
Melchior M, Caspi A, Milne BJ, Danese A, Poulton R, Moffitt TE: Work stress precipitates depression and anxiety in young, working women and men. Psychol Med 2007;37: 1119-1129.

-12 Caspi A, Sugden K, Moffitt TE, Taylor A Craig IW, Harrington H, McClay J, Mill J, Martin J, Braithwaite A, Poulton R: Influence of life stress on depression: moderation by a polymorphism in the 5-HTT gene. Science 2003;301:386-389.

13 Barha CK, Brummelte S, Lieblich SE, Galea LA: Chronic restraint stress in adolescence differentially influences hypothalamic-pituitary-adrenal axis function and adult hippocampal neurogenesis in male and female rats. Hippocampus 2011;21:1216-1227.

14 Bourke CH, Neigh GN: Behavioral effects of chronic adolescent stress are sustained and sexually dimorphic. Horm Behav 2011;60: 112-120. 
15 Jankord R, Solomon MB, Albertz J, Flak JN, Zhang R, Herman JP: Stress vulnerability during adolescent development in rats. Endocrinology 2011;152:629-638.

16 Clark C, Caldwell T, Power C, Stansfeld SA: Does the influence of childhood adversity on psychopathology persist across the lifecourse? A 45-year prospective epidemiologic study. Ann Epidemiol 2010;20:385-394.

- 17 Heim C, Newport DJ, Mletzko T, Miller AH, Nemeroff CB: The link between childhood trauma and depression: insights from HPA axis studies in humans. Psychoneuroendocrinology 2008;33:693-710.

- 18 Heim C, Mletzko T, Purselle D, Musselman DL, Nemeroff CB: The dexamethasone/corticotropin-releasing factor test in men with major depression: role of childhood trauma. Biol Psychiatry 2008;63:398-405.

$\checkmark 19$ de Kloet CS, Vermetten E, Geuze E, Kavelaars A, Heijnen CJ, Westenberg HG: Assessment of HPA-axis function in posttraumatic stress disorder: pharmacological and non-pharmacological challenge tests, a review. J Psychiatr Res 2006;40:550-567.

-20 Tsigos C, Chrousos GP: Hypothalamic-pituitary-adrenal axis, neuroendocrine factors and stress. J Psychosom Res 2002;53:865-871.

21 Miller GE, Chen E, Zhou ES: If it goes up, must it come down? Chronic stress and the hypothalamic-pituitary-adrenocortical axis in humans. Psychol Bull 2007;133:25-45.

-22 Wessa M, Rohleder N, Kirschbaum C, Flor H: Altered cortisol awakening response in posttraumatic stress disorder. Psychoneuroendocrinology 2006;31:209-215.

-23 Keeshin BR, Strawn JR, Out D, Granger DA, Putnam FW: Cortisol awakening response in adolescents with acute sexual abuse related posttraumatic stress disorder. Depress Anxiety 2014;31:107-114.

-24 de Kloet CS, Vermetten E, Heijnen CJ, Geuze E, Lentjes EG, Westenberg HG: Enhanced cortisol suppression in response to dexamethasone administration in traumatized veterans with and without posttraumatic stress disorder. Psychoneuroendocrinology 2007;32: 215-226.

-25 Yehuda R, Halligan SL, Golier JA, Grossman $\mathrm{R}$, Bierer LM: Effects of trauma exposure on the cortisol response to dexamethasone administration in PTSD and major depressive disorder. Psychoneuroendocrinology 2004; 29:389-404.

26 Rinne T, de Kloet ER, Wouters L, Goekoop JG, DeRijk RH, van den Brink W: Hyperresponsiveness of hypothalamic-pituitary-adrenal axis to combined dexamethasone/corticotropin-releasing hormone challenge in female borderline personality disorder subjects with a history of sustained childhood abuse. Biol Psychiatry 2002;52:1102-1112.
27 MacMillan HL, Georgiades K, Duku EK, Shea A, Steiner M, Niec A, Tanaka M, Gensey S, Spree S, Vella E, Walsh CA, De Bellis MD, Van der Meulen J, Boyle MH, Schmidt LA: Cortisol response to stress in female youths exposed to childhood maltreatment: results of the youth mood project. Biol Psychiatry 2009; 66:62-68.

28 Cohen SI: Cushing's syndrome: a psychiatric study of 29 patients. Br J Psychiatry 1980;136: 120-124.

29 Dorn LD, Burgess ES, Friedman TC, Dubbert B, Gold PW, Chrousos GP: The longitudinal course of psychopathology in Cushing's syndrome after correction of hypercortisolism. J Clin Endocrinol Metab 1997;82:912-919.

30 Flitsch J, Spitzner S, Ludecke DK: Emotional disorders in patients with different types of pituitary adenomas and factors affecting the diagnostic process. Exp Clin Endocrinol Diabetes 2000;108:480-485.

31 Starkman MN, Schteingart DE, Schork MA: Cushing's syndrome after treatment: changes in cortisol and ACTH levels, and amelioration of the depressive syndrome. Psychiatry Res 1986;19:177-188.

32 Fardet L, Petersen I, Nazareth I: Suicidal behavior and severe neuropsychiatric disorders following glucocorticoid therapy in primary care. Am J Psychiatry 2012;169:491-497.

-33 Jernigan TL, Trauner DA, Hesselink JR, Tallal PA: Maturation of human cerebrum observed in vivo during adolescence. Brain 1991;114: 2037-2049.

34 Giedd JN: Structural magnetic resonance im aging of the adolescent brain. Ann NY Acad Sci 2004;1021:77-85.

35 Weaver IC, Cervoni N, Champagne FA, D’Alessio AC, Sharma S, Seckl JR, Dymov S, Szyf M, Meaney MJ: Epigenetic programming by maternal behavior. Nat Neurosci 2004;7: 847-854.

36 Weaver IC, Meaney MJ, Szyf M: Maternal care effects on the hippocampal transcriptome and anxiety-mediated behaviors in the offspring that are reversible in adulthood. Proc Natl Acad Sci USA 2006;103:3480-3485.

37 Dwivedi Y, Rizavi HS, Pandey GN: Antidepressants reverse corticosterone-mediated decrease in brain-derived neurotrophic factor expression: differential regulation of specific exons by antidepressants and corticosterone. Neuroscience 2006;139:1017-1029.

- 38 Roth TL, Lubin FD, Funk AJ, Sweatt JD: Lasting epigenetic influence of early-life adversity on the BDNF gene. Biol Psychiatry 2009;65: 760-769.

39 Wochnik GM, Ruegg J, Abel GA, Schmidt U, Holsboer F, Rein T: FK506-binding proteins 51 and 52 differentially regulate dynein interaction and nuclear translocation of the glucocorticoid receptor in mammalian cells. J Biol Chem 2005;280:4609-4616.
40 Binder EB, Salyakina D, Lichtner P, Wochnik GM, Ising M, Putz B, Papiol S, Seaman S, Lucae S, Kohli MA, Nickel T, Kunzel HE, Fuchs B, Majer M, Pfennig A, Kern N, Brunner J, Modell S, Baghai T, Deiml T, Zill P, Bondy B, Rupprecht R, Messer T, Kohnlein O, Dabitz H, Bruckl T, Muller N, Pfister H, Lieb R, Mueller JC, Lohmussaar E, Strom TM, Bettecken T, Meitinger T, Uhr M, Rein T, Holsboer F, Muller-Myhsok B: Polymorphisms in FKBP5 are associated with increased recurrence of depressive episodes and rapid response to antidepressant treatment. Nat Genet 2004;36:1319-1325.

41 Binder EB, Bradley RG, Liu W, Epstein MP, Deveau TC, Mercer KB, Tang Y, Gillespie CF, Heim CM, Nemeroff CB, Schwartz AC, Cubells JF, Ressler KJ: Association of FKBP5 polymorphisms and childhood abuse with risk of posttraumatic stress disorder symptoms in adults. JAMA 2008:299:1291-1305.

42 Xie P, Kranzler HR, Poling J, Stein MB, Anton RF, Farrer LA, Gelernter J: Interaction of FKBP5 with childhood adversity on risk for post-traumatic stress disorder. Neuropsychopharmacology 2010;35:1684-1692.

43 Willour VL, Chen H, Toolan J, Belmonte P, Cutler DJ, Goes FS, Zandi PP, Lee RS, MacKinnon DF, Mondimore FM, Schweizer B, DePaulo JR, Jr., Gershon ES, McMahon FJ, Potash JB: Family-based association of FKBP5 in bipolar disorder. Mol Psychiatry 2009;14: 261-268.

-44 Lee RS, Tamashiro KL, Yang X, Purcell RH, Harvey A, Willour VL, Huo Y, Rongione M, Wand GS, Potash JB: Chronic corticosterone exposure increases expression and decreases deoxyribonucleic acid methylation of Fkbp5 in mice. Endocrinology 2010;151:4332-4343.

$\checkmark 45$ Lee RS, Tamashiro KL, Yang X, Purcell RH, Huo Y, Rongione M, Potash JB, Wand GS: A measure of glucocorticoid load provided by DNA methylation of Fkbp5 in mice. Psychopharmacology (Berl) 2011;218:303-312.

46 Klengel T, Mehta D, Anacker C, Rex-Haffner M, Pruessner JC, Pariante CM, Pace TW, Mercer KB, Mayberg HS, Bradley B, Nemeroff CB, Holsboer F, Heim CM, Ressler KJ, Rein T, Binder EB: Allele-specific FKBP5 DNA demethylation mediates gene-childhood trauma interactions. Nat Neurosci 2013; 16:33-41.

-47 Tsankova NM, Berton O, Renthal W, Kumar A, Neve RL, Nestler EJ: Sustained hippocampal chromatin regulation in a mouse model of depression and antidepressant action. Nat Neurosci 2006;9:519-525.

48 Elliott E, Ezra-Nevo G, Regev L, Neufeld-Cohen A, Chen A: Resilience to social stress coincides with functional DNA methylation of the Crf gene in adult mice. Nat Neurosci 2010; 13:1351-1353. 
-49 Niwa M, Jaaro-Peled H, Tankou S, Seshadri S, Hikida T, Matsumoto Y, Cascella NG, Kano S, Ozaki N, Nabeshima T, Sawa A: Adolescent stress-induced epigenetic control of dopaminergic neurons via glucocorticoids. Science 2013;339:335-339.

50 Guidotti G, Calabrese F, Anacker C, Racagni G, Pariante CM, Riva MA: Glucocorticoid receptor and FKBP5 expression is altered following exposure to chronic stress: modulation by antidepressant treatment. Neuropsychopharmacology 2013;38:616-627.

- 51 Surjit M, Ganti KP, Mukherji A, Ye T, Hua G, Metzger D, Li M, Chambon P: Widespread negative response elements mediate direct repression by agonist-liganded glucocorticoid receptor. Cell 2011;145:224-241.

52 Ramamoorthy S, Cidlowski JA: Ligand-induced repression of the glucocorticoid receptor gene is mediated by an NCoR1 repression complex formed by long-range chromatin interactions with intragenic glucocorticoid response elements. Mol Cell Biol 2013;33:17111722.

-53 Reynolds PD, Ruan Y, Smith DF, Scammell JG: Glucocorticoid resistance in the squirrel monkey is associated with overexpression of the immunophilin FKBP51. J Clin Endocrinol Metab 1999;84:663-669.

54 Denny WB, Valentine DL, Reynolds PD, Smith DF, Scammell JG: Squirrel monkey immunophilin FKBP51 is a potent inhibitor of glucocorticoid receptor binding. Endocrinology 2000;141:4107-4113.

55 Malkoski SP, Dorin RI: Composite glucocorticoid regulation at a functionally defined negative glucocorticoid response element of the human corticotropin-releasing hormone gene. Mol Endocrinol 1999;13:1629-1644.

- 56 Guardiola-Diaz HM, Kolinske JS, Gates LH, Seasholtz AF: Negative glucorticoid regulation of cyclic adenosine $3^{\prime}, 5^{\prime}$-monophosphate-stimulated corticotropin-releasing hormone-reporter expression in AtT-20 cells. Mol Endocrinol 1996;10:317-329.

57 Laryea G, Schutz G, Muglia LJ: Disrupting hypothalamic glucocorticoid receptors causes HPA axis hyperactivity and excess adiposity. Mol Endocrinol 2013;27:1655-1665.

58 Sharma D, Bhave S, Gregg E, Uht R: Dexamethasone induces a putative repressor complex and chromatin modifications in the $\mathrm{CRH}$ promoter. Mol Endocrinol 2013;27:11421152.

59 Evans AN, Liu Y, Macgregor R, Huang V, Aguilera G: Regulation of hypothalamic corticotropin-releasing hormone transcription by elevated glucocorticoids. Mol Endocrinol 2013;27:1796-1807.

60 Hetman M, Kanning K, Cavanaugh JE, Xia Z: Neuroprotection by brain-derived neurotrophic factor is mediated by extracellular signal-regulated kinase and phosphatidylinositol 3-kinase. J Biol Chem 1999;274:2256922580 .
61 Son JH, Chun HS, Joh TH, Cho S, Conti B, Lee JW: Neuroprotection and neuronal differentiation studies using substantia nigra dopaminergic cells derived from transgenic mouse embryos. J Neurosci 1999;19:10-20.

62 Bali B, Ferenczi S, Kovacs KJ: Direct inhibitory effect of glucocorticoids on corticotrophin-releasing hormone gene expression in neurones of the paraventricular nucleus in rat hypothalamic organotypic cultures. J Neuroendocrinol 2008;20:1045-1051.

63 Suri D, Vaidya VA: Glucocorticoid regulation of brain-derived neurotrophic factor: relevance to hippocampal structural and functional plasticity. Neuroscience 2013;239:196213.

64 Barbany G, Persson H: Regulation of neurotrophin mRNA expression in the rat brain by glucocorticoids. Eur J Neurosci 1992;4:396403.

65 De Bosscher K, Vanden Berghe W, Haegeman G: The interplay between the glucocorticoid receptor and nuclear factor-kappaB or activator protein-1: molecular mechanisms for gene repression. Endocr Rev 2003;24:488522.

66 Glass CK, Saijo K: Nuclear receptor transrepression pathways that regulate inflammation in macrophages and T cells. Nat Rev Immunol 2010;10:365-376.

67 Polman JA, Welten JE, Bosch DS, de Jonge RT, Balog J, van der Maarel SM, de Kloet ER, Datson NA: A genome-wide signature of glucocorticoid receptor binding in neuronal PC12 cells. BMC Neurosci 2012;13:118.

68 Irizarry RA, Ladd-Acosta C, Carvalho B, Wu $\mathrm{H}$, Brandenburg SA, Jeddeloh JA, Wen B, Feinberg AP: Comprehensive high-throughput arrays for relative methylation (CHARM). Genome Res 2008;18:780-790.

69 Polman JA, de Kloet ER, Datson NA: Two populations of glucocorticoid receptor-binding sites in the male rat hippocampal genome. Endocrinology 2013;154:1832-1844.

-70 McKlveen JM, Myers B, Flak JN, Bundzikova J, Solomon MB, Seroogy KB, Herman JP: Role of prefrontal cortex glucocorticoid receptors in stress and emotion. Biol Psychiatry 2013; 74:672-679.

71 Touma C, Gassen NC, Herrmann L, CheungFlynn J, Bull DR, Ionescu IA, Heinzmann JM, Knapman A, Siebertz A, Depping AM, Hartmann J, Hausch F, Schmidt MV, Holsboer F, Ising M, Cox MB, Schmidt U, Rein T: FK506 binding protein 5 shapes stress responsiveness: modulation of neuroendocrine reactivity and coping behavior. Biol Psychiatry 2011; 70:928-936.

72 Casey BJ, Glatt CE, Tottenham N, Soliman F, Bath K, Amso D, Altemus M, Pattwell S, Jones R, Levita L, McEwen B, Magarinos AM, Gunnar M, Thomas KM, Mezey J, Clark AG, Hempstead BL, Lee FS: Brain-derived neurotrophic factor as a model system for examining gene by environment interactions across development. Neuroscience 2009;164:108120.
73 Pietersen CY, Lim MP, Macey L, Woo TU, Sonntag KC: Neuronal type-specific gene expression profiling and laser-capture microdissection. Methods Mol Biol 2011;755:327343.

74 Kim YG, Cha J, Chandrasegaran S: Hybrid restriction enzymes: zinc finger fusions to Fok I cleavage domain. Proc Natl Acad Sci USA 1996;93:1156-1160.

75 Bibikova M, Beumer K, Trautman JK, Carroll $\mathrm{D}$ : Enhancing gene targeting with designed zinc finger nucleases. Science 2003;300:764.

76 Chaikind B, Ostermeier M: Directed evolution of improved zinc finger methyltransferases. PLoS One 2014;9:e96931.

-77 Silberstein S, Vogl AM, Refojo D, Senin SA, Wurst W, Holsboer F, Deussing JM, Arzt E: Amygdaloid pERK1/2 in corticotropin-releasing hormone overexpressing mice under basal and acute stress conditions. Neuroscience 2009;159:610-617.

78 Polanczyk G, Caspi A, Williams B, Price TS, Danese A, Sugden K, Uher R, Poulton R, Moffitt TE: Protective effect of CRHR1 gene variants on the development of adult depression following childhood maltreatment: replication and extension. Arch Gen Psychiatry 2009;66:978-985.

79 Bale TL, Vale WW: Increased depression-like behaviors in corticotropin-releasing factor receptor-2-deficient mice: sexually dichotomous responses. J Neurosci 2003;23:52955301.

80 Roy A, Hodgkinson CA, Deluca V, Goldman D, Enoch MA: Two HPA axis genes, CRHBP and FKBP5, interact with childhood trauma to increase the risk for suicidal behavior. J Psychiatr Res 2012;46:72-79.

81 Hartmann J, Wagner KV, Dedic N, Marinescu D, Scharf SH, Wang XD, Deussing JM, Hausch F, Rein T, Schmidt U, Holsboer F, Muller MB, Schmidt MV: Fkbp52 heterozygosity alters behavioral, endocrine and neurogenetic parameters under basal and chronic stress conditions in mice. Psychoneuroendocrinology 2012;37:2009-2021.

-82 Roy A, Gorodetsky E, Yuan Q, Goldman D, Enoch MA: Interaction of FKBP5, a stressrelated gene, with childhood trauma increases the risk for attempting suicide. Neuropsychopharmacology 2010;35:1674-1683.

83 Kim JJ, Mandelli L, Lim S, Lim HK, Kwon OJ, Pae CU, Serretti A, Nimgaonkar VL, Paik IH, Jun TY: Association analysis of heat shock protein 70 gene polymorphisms in schizophrenia. Eur Arch Psychiatry Clin Neurosci 2008;258:239-244.

84 Kowalczyk M, Owczarek A, Suchanek R, Paul-Samojedny M, Fila-Danilow A, Borkowska P, Kucia K, Kowalski J: Heat shock protein 70 gene polymorphisms are associated with paranoid schizophrenia in the Polish population. Cell Stress Chaperones 2014;19: 205-215. 
85 Conway-Campbell BL, George CL, Pooley JR, Knight DM, Norman MR, Hager GL, Lightman SL: The HSP90 molecular chaperone cycle regulates cyclical transcriptional dynamics of the glucocorticoid receptor and its coregulatory molecules $\mathrm{CBP} / \mathrm{p} 300$ during ultradian ligand treatment. Mol Endocrinol 2011;25: 944-954.

-86 Djordjevic A, Adzic M, Djordjevic J, Radojcic MB: Stress type dependence of expression and cytoplasmic-nuclear partitioning of glucocorticoid receptor, hsp90 and hsp70 in Wistar rat brain. Neuropsychobiology 2009;59:213221.

87 McGowan PO, Sasaki A, D’Alessio AC, Dymov S, Labonte B, Szyf M, Turecki G, Meaney MJ: Epigenetic regulation of the glucocorticoid receptor in human brain associates with childhood abuse. Nat Neurosci 2009;12:342348.

88 van West D, Van Den Eede F, Del-Favero J, Souery D, Norrback KF, Van Duijn C, Sluijs S, Adolfsson R, Mendlewicz J, Deboutte D, Van Broeckhoven C, Claes S: Glucocorticoid receptor gene-based SNP analysis in patients with recurrent major depression. Neuropsychopharmacology 2006;31:620-627.

-89 Szczepankiewicz A, Leszczynska-Rodziewicz A, Pawlak J, Rajewska-Rager A, DmitrzakWeglarz M, Wilkosc M, Skibinska M, Hauser $\mathrm{J}$ : Glucocorticoid receptor polymorphism is associated with major depression and predominance of depression in the course of bipolar disorder. J Affect Disord 2011;134:138144.
90 Schmidt U, Holsboer F, Rein T: Role of the hsp70 cochaperone BAG1 in glucocorticoid receptor function and stress-related diseases. Proc Natl Acad Sci USA 2008; 105:E101, author reply E102.

91 Maeng S, Hunsberger JG, Pearson B, Yuan P, Wang Y, Wei Y, McCammon J, Schloesser RJ, Zhou R, Du J, Chen G, McEwen B, Reed JC, Manji HK: BAG1 plays a critical role in regulating recovery from both manic-like and depression-like behavioral impairments. Proc Natl Acad Sci USA 2008;105:8766-8771.

92 Berton O, McClung CA, Dileone RJ, Krishnan V, Renthal W, Russo SJ, Graham D, Tsankova NM, Bolanos CA, Rios M, Monteggia LM, Self DW, Nestler EJ: Essential role of BDNF in the mesolimbic dopamine pathway in social defeat stress. Science 2006;311:864868.

93 Chen ZY, Jing D, Bath KG, Ieraci A, Khan T, Siao CJ, Herrera DG, Toth M, Yang C, McEwen BS, Hempstead BL, Lee FS: Genetic variant BDNF (Val66Met) polymorphism alters anxiety-related behavior. Science 2006;314: 140-143.

94 Reddy TE, Gertz J, Crawford GE, Garabedian MJ, Myers RM: The hypersensitive glucocorticoid response specifically regulates period 1 and expression of circadian genes. Mol Cell Biol 2012;32:3756-3767.
95 Giglio LM, Magalhaes PV, Kapczinski NS Walz JC, Kapczinski F: Functional impact of biological rhythm disturbance in bipolar disorder. J Psychiatr Res 2010;44:220-223.

$\$ 96$ Harvey AG: Sleep and circadian rhythms in bipolar disorder: seeking synchrony, harmony, and regulation. Am J Psychiatry 2008; 165:820-829.

97 Anacker C, Cattaneo A, Musaelyan K, Zunszain PA, Horowitz M, Molteni R, Luoni A, Calabrese F, Tansey K, Gennarelli M, Thuret S, Price J, Uher R, Riva MA, Pariante CM: Role for the kinase SGK1 in stress, depression, and glucocorticoid effects on hippocampal neurogenesis. Proc Natl Acad Sci USA 2013;110:8708-8713.

98 Miyata S, Koyama Y, Takemoto K, Yoshikawa $\mathrm{K}$, Ishikawa $\mathrm{T}$, Taniguchi $\mathrm{M}$, Inoue $\mathrm{K}$, Aoki M, Hori O, Katayama T, Tohyama M: Plasma corticosterone activates SGK1 and induces morphological changes in oligodendrocytes in corpus callosum. PLoS One 2011;6:e19859.

-99 Matthews M, Bondi C, Torres G, Moghaddam B: Reduced presynaptic dopamine activity in adolescent dorsal striatum. Neuropsychopharmacology 2013;38:1344-1351.

100 Zhou QY, Palmiter RD: Dopamine-deficient mice are severely hypoactive, adipsic, and aphagic. Cell 1995;83:1197-1209.

101 Rani CS, Elango N, Wang SS, Kobayashi K, Strong R: Identification of an activator protein-1-like sequence as the glucocorticoid response element in the rat tyrosine hydroxylase gene. Mol Pharmacol 2009;75:589598. 